\title{
Community-Based Halal Tourism Village: Insight from Setanggor Village
}

\author{
Hendri Hermawan Adinugraha \\ Institut Agama Islam Negeri Pekalongan, Indonesia \\ email: hendri.hermawan@iainpekalongan.ac.id
}

\section{Razie Bin Nasarruddin}

Armag Oil \& Gas Academy, Malaysia

email: razie.nasar@gmail.com

\begin{abstract}
Ahmad Rofiq
Universitas Islam Negeri Walisongo Semarang, Indonesia

email: ahmad_rofiq.walisongo.ac.id
\end{abstract}

\section{Ahmad Hasan Asy'ari Ulama'i}

Universitas Islam Negeri Walisongo Semarang, Indonesia email: hasan.ulamai@walisongo.ac.id

\section{Ade Yusuf Mujaddid}

Universitas Islam Negeri Walisongo Semarang, Indonesia email: adeyusufm@walisongo.ac.id

\section{Mila Sartika}

Universitas Dian Nuswantoro, Indonesia

email:mila.sartika@dsn.dinus.ac.id

\begin{abstract}
This research aims to describe the development model of Setanggor halal tourism village. This research uses qualitative research methods with a descriptive approach. The results showed that halal tourism in Setanggor village was developed through active community participation with the village government through a tourism village model based on community and halal values. The development of halal tourism villages in Setanggor is not able to be separated from religious values. As a result, Community-Based Halal Tourism in Setanggor village combines community-based tourism and halal-based tourism that will eventually serve as a model for community-based halal tourism. The growth of the halal tourism sector in Setanggor village has also provided positive benefits for enhancing the local community's well-being. In addition to the
\end{abstract}

Economica: Jurnal Ekonomi Islam - Volume 11, Nomor 1 (2020) 
Hendri Hermawan Adinugraha et al.

community's active role, the legality of the Setanggor halal tourism village is also supported by the local government of NTB and the Indonesian Council of Ulama.

Keywords: Local community; halal tourism; community-based halal tourism

Abstrak: Penelitian ini bertujuan untuk mendeskripsikan model pengembangan desa wisata halal Setanggor. Penelitian ini menggunakan metode penelitian kualitatif dengan pendekatan deskriptif. Hasil penelitian menunjukkan bahwa wisata halal di Desa Setanggor dikembangkan melalui partisipasi aktif masyarakat dengan pemerintah desa melalui model "Desa Wisata Halal Berbasis Masyarakat". Pengembangan desa wisata halal di Setanggor tidak lepas dari nilai-nilai religi. Oleh karena itu, CBT di desa Setanggor yang merupakan gabungan antara pariwisata berbasis komunitas dengan pariwisata berbasis halal pada akhirnya menjadi role model bagi wisata halal berbasis komunitas. Pertumbuhan sektor wisata halal di desa Setanggor juga memberikan manfaat positif bagi peningkatan kesejahteraan masyarakat setempat. Selain peran aktif masyarakat, legalitas desa wisata halal Setanggor juga didukung oleh pemerintah daerah NTB dan Majelis Ulama Indonesia.

Kata Kunci: Komunitas lokal; wisata halal; wisata halal berbasis komunitas 


\section{Introduction}

The halal business trend in the world today continues to show significant progress (Ali et al. 2021), especially in businesses in the halal travel and halal recreation sector (Thomson Reuters 2018). Demand for halal tourism in Indonesia and the world is increasing. Various countries globally are equally racing to develop halal tourism with consideration because this sector is considered to have promising prospects in increasing foreign exchange of their respective countries (Peristiwo 2020). When someone talks about halal, it does not refer to food alone but everything in everyday life (Adinugraha and Sartika 2019). Halal covers all aspects of human life without exception. A Muslim is obliged to ascertain the legal status of his food and drink before consuming it (Tawil et al. 2015). Likewise, if he travels, a Muslim is obliged to ensure the legal status of tourist destinations permitted by sharia to be visited because prohibited tourism is unlawful (Sukardi, Fachrurazi, and Supriyanto 2019).

Applying the halal concept in the tourism sector has become a trend and need for Muslim and non-Muslim countries. Halal tourism is a rapidly expanding market segment not only in Muslim countries but globally. Based on this growing phenomenon, combined with the increasing number of Muslim tourists worldwide, some non-Muslim countries have also begun various strategies to benefit from halal tourism. The market for halal tourism is dominated by these countries, namely Bahrain, Jordan, Kuwait, Oman, Qatar, Saudi Arabia, United Arab Emirates, Malaysia, Indonesia, Brunei, and Muslim tourists from South Asia, Europe, the United States, and Britain (Mohsin, Ramli, and Alkhulayfi 2016).

In early 2019, Indonesia was awarded as the world's best halal tourism destination 2019 based on the Global Muslim Travel Index (GMTI), outperforming 130 destinations from around the world. Tourism has a vital role in encouraging an increase in the welfare of local communities through 
Hendri Hermawan Adinugraha et al.

the provision of jobs for the community (Mastercard-CrescentRating 2018). In Indonesia, through the Ministry of Tourism, it is constantly campaigning for halal tourism programs for its regional heads. As an appreciation for the regions that have sought to develop halal tourism (Rehman 2020), the Ministry of Tourism gave the award to the five best halal tourism destinations, and Nusa Tenggara Barat (NTB) ranked the best in the event-based in Indonesia Muslim Travel Index (IMTI) year 2019.

Halal tourism in NTB is a new icon of tourism development that must be developed and requires attention because it is expected to attract and attract tourists both domestic and foreign tourists. Therefore, the Provincial and Regional Governments strive to develop halal tourism and possible (Satriana and Faridah 2018). At the World Halal Travel Summit organized by the UAE Abu Dhabi in 2015 and 2016, NTB was chosen as the world champion as The World's Best Halal Honeymoon Destination and The World's Best Halal Tourism Destination (Aulia Ramadhani, Kurniawati, and Hadi Nata 2020).

The tourism sector is also one of the greatest potentials in the countryside. Recorded from the Village Potential in 2018, 1,734 tourist villages throughout Indonesia (Indonesian Central Bureau of Statistics, 2020). Setanggor Halal Tourism Village is one of the most up-to-date rural halal tourist destinations in NTB and was inaugurated by the Ministry of Rural Development and Transmigration of Indonesia on Saturday, March 23, 2019. Setanggor Village is an attractive holiday destination with the concept of religious tourism wrapped in the beauty of rural nature and local wisdom. Setanggor Village has a variety of natural, simple, and traditional community activities. Setanggor village is also part of sustainable halal tourism in NTB which creates a competitive advantage in attracting tourists to visit NTB for halal tourism purposes that uphold Islamic values. Because, in essence, Islamic values have a positive and significant influence on the satisfaction of Muslim tourists partially and simultaneously (Rahmiati and Fajarsari 2020). 
The development of halal tourism destinations as one of the objects that can be sold to attract tourists is a challenge for each region (Chin, HaddockFraser and Hampton, 2017; Taqwiem, Al Rasyid Muhammad and Maulidi, 2020) because conventional tourism already exists first, such as Gili Trawangan, Senggigi Beach, and Kuta Lombok which still dominates tourist visits with Lombok's natural marine beauty and is conventional (Rahmawati et al. 2021). Thus, the innovation model of halal tourist destinations in the countryside and the need for active support and participation from local communities is fundamental and urgent in welcoming the development of halal tourism in Lombok, NTB, Indonesia.

Among the challenges in the halal industry is the diversity and fragmentation of the tourism industry in measuring the economic impact of tourism itself (Taylor, 2005; Davidson, 2005; Vanhove, 2010). In addition, there is some ambiguity about the interpretation of the concept of halal tourism, which influences the approach to its implementation (Muhamad et al. 2019). Tourism is also, by some experts, considered dangerous for the environment. Some worried Muslim scholars even oppose the existence of tourism because they think it will lead to the exchange or mixing of various cultural traditions, values, beliefs, and attitudes that can erode Islamic values and culture (Sanad, Kassem, and Scott 2010).

This study emphasizes the development of halal tourism villages in rural areas based on the empowerment of local communities, which is carried out after analyzing and examining the potential and characteristics of halal tourism villages in Setanggor. Therefore, the development of halal tourism right in the countryside through Setanggor Village, Lombok, Nusa Tenggara Barat (NTB) can be designed and applied optimally to realize sustainable rural halal tourism destinations. This study uses descriptive qualitative research methods to describe and explain the development of halal tourism villages based on the Setanggor community who have ambitions to develop halal tourism in the countryside. 
Hendri Hermawan Adinugraha et al.

\section{Methods}

This research was conducted in the Halal Tourism Village of Setanggor using qualitative methods (field research), which are descriptive. Setanggor Village is the only tourist village that has halal branding in Indonesia. The research data technique used the triangulation method, namely participant observation, in-depth interviews, and documentation. Then the analysis uses interactive analysis techniques (Miles and Huberman, 1994; Morrow and Smith, 2000).

The reason for choosing Setanggor Village as the research location is that Setanggor Village is the only tourism village with a halal tourism village branding in Indonesia. Currently, Setanggor Village has many achievements in the tourism sector. Some of the awards won include the Development of the Best Tourism Village 2017, the Top 10 National Level Tourism Villages 2017, Champion of Gendang Belek TNI Anniversary 2017, Tourism Development Innovation Village in Central Lombok 2019 (1st Champion), BUMN Present Recipient Program for 2018.

\section{Result and discussion}

\section{Profile of Setanggor village}

Setanggor in Lombok language means "calling," the population of Setanggor village in 2017 is 4,179 consisting of 2,065 men and 2,114 women. Setanggor village has 14 hamlets and is one of the tourist villages in Praya Barat District, Central Lombok Regency, West Nusa Tenggara Province (NTB). The distance from Lombok International Airport is only around 3 kilometers and is about 5 kilometers from the center of the pottery craft in Penujak Village. The provincial road traverses Setanggor village connects with the South Bagin Lobar Tourism Area. Setanggor Village is also a Mandalika Special Economic Zone (Indonesia Tourism Development Corporation, 2018). 
Setanggor village has a myriad of tourism potential that can attract the attention of local and foreign tourists. The potential of Setanggor village in terms of tradition, art, and culture is still solid. The local community and village government permanently preserve the values of art, tradition, and culture. They can also collaborate the beauty of nature and the thick cultural values that make every visitor who comes to feel fascinated by its beauty (Assidiq, Hermanto, and Rinuastuti 2021). For tourists or visitors who visit Setanggor village, they will be spoiled by the green landscape of the village by rice and palm trees, the many displays of art and culture in the village (Busaini et al. 2020). Starting from traditional musical instruments, art studios, dance groups, hundreds of years old gong instruments, gamelan groups played from children to adults, and reading manuscripts (called by Lontar) at certain times. All the richness of cultural arts makes Setanggor Village different from other villages (Utami 2020). Therefore, Setanggor Village is now in demand by tourists, both domestic and foreign, because it has various potentials for rural local wisdom and its natural beauty, a unique attraction. According to Sirajuddin as Secretary of Tourism Awareness Group, there are at least 14 tourism spots that can be enjoyed in this village, including Cultural Arts tours, more than 200 years of Sacred Gong, Weaving tours, Animal Husbandry tours, Agricultural tourism, Agro tourism, English Fun, Religious tourism, and Cassava Garden (Feriyadin, Saufi, and Rinuastuti 2021).

So it is not surprising that Setanggor village has had many achievements in the field of tourism. The awards that have been achieved include the Best Tourism Village Development 2017, the Top 10 National Level Tourism Village 2017, Champion Gendang Belek 2017 TNI Anniversary, Champion I Village Tourism Development Innovation in Central Lombok 2018, Recipients of BUMN Present for 2018. 
Hendri Hermawan Adinugraha et al.

\section{The importance of Setanggor halal tourism villages}

At present, tourism has grown significantly in economic and social interests. The fastest-growing economic sector in most industrialized countries over the past few years is the services sector. One of the most significant service industry segments is travel and tourism (Kaur and Kochar 2017). Therefore, tourism directly or indirectly has been at the forefront of creating a global society (Robinson, Lück, and Smith, 2020; Kulak, 2020; Zabarna and Averikhina, 2020).

The current social phenomenon of rural tourism has become a new development in the tourism industry domestically and abroad (Dolezal and Novelli, 2020; Gutkevych and Haba, 2020; Qiu, Zhou, and Kim, 2021). Rural tourism in several countries such as Malaysia, South Africa, Spain, Britain, the United States, Japan, Portugal, and Australian tourism are stimulants capable of revitalizing the rural economy. Village tourism is one of the rural tourism products. The tourism village was developed based on the uniqueness of the community to create variations such as villages that focus on the beauty of natural resources, agricultural or fishery activities, cultural heritage, traditional architecture, local wisdom, traditions, customs, and other charms. Tourism villages are also alternative tourism that can contribute to positive social, economic, and cultural resources in rural areas (Hartiningsih, Adhika, and Arcana 2017).

Besides, the search for a rural atmosphere for peace, rest, and recreation has also become a common trend in current tourism practices both at the regional, national, and international levels, so that most EU countries pay special attention to the rural tourism sector through local development policies (Mai and Doo-Chul, 2021; Lee, Olasehinde-Williams and Akadiri, 2021; Aprilani, Yuliarmi and Marhaeni, 2021; Wikantiyoso et al., 2021). These efforts are in line with strengthening the comprehensive economic development of rural areas, given the magnitude of the tourism value, if 
viewed from an economic, environmental, social, and cultural perspective (Drăgulănescu and Ivan 2012).

For example, in Serbia, rural tourism displays the uniqueness of local characters initiated and controlled by local communities. Rural tourism offers new opportunities and possibilities for the local population's economic prosperity and influences the positive attitude of tourism development in the aggregate (Maksimović, Urošević, and Damnjanović 2015). In China, tourism has been adopted as a means to improve the rural economy. As a result, tourism has increased significantly in rural communities. This situation mainly occurs in traditional villages because China is famous for its historical and cultural heritage (Xu, Zhang, and Tian 2017). In Romania, the popularity of rural areas located in mountainous regions rich in natural charm, villages in the mountains are places to spend holidays by urban people. Therefore, almost all mountainous areas can provide excellent opportunities for developing various forms of rural tourism by utilizing their natural resources through forms of rural tourism (Ciolac et al. 2017).

One area rich in the charm of natural beauty and the uniqueness of its cultural traditions is the village of Setanggor, which now has a Setanggor Halal Tourism Village brand. The stakeholders who manage the halal tourism god Setanggor agreed that thanks to the existence of the tourist village, it has a positive economic effect on the host community, as the community's income is increasing and can absorb local labor. This is in line with the findings of the research conducted by Shahmirzadi (2018), which revealed that tourism's role in helping develop tourist areas had become a new solution for everyone. Rural tourism is one form of tourism that is being favored by today's society.

In this case, the development of the tourism sector in the Setanggor halal tourism village has become a particular concern by the central government and regional governments. This can be seen from the government's efforts in issuing a legal framework for its development. For example, according to the Law of the Republic of Indonesia Number 10 of 2009 concerning Tourism, the 
Hendri Hermawan Adinugraha et al.

nature, flora, fauna, as well as ancient relics, history, arts, and culture, are crucial resources for developing tourism to increase people's prosperity. According to the Law of the Republic of Indonesia Number 33 the Year 2014 concerning Halal Product Guarantee and Government Regulation of the Republic of Indonesia No 31 the Year 2019 concerning Regulation of Implementation of Law Number 33 the Year 2014 concerning Guaranteed Halal Products, the state is obliged to provide protection and guarantee about halal products or services that are consumed and used or utilized by the community. The existence of halal certification in various countries, both in Muslim countries and in non-Muslim countries, is no longer limited to efforts to protect Muslims against halal and illicit substances but has become a business commodity (Zainuddin et al. 2019). This includes the tourism sector.

Furthermore, the Indonesian Council of Ulama (MUI) National Sharia Board (DSN) through the Fatwa No: 108/DSN-MUI/X/2016 Concerning Guidelines for Organizing Sharia-Based Tourism. MUI considers that the sharia-based tourism sector is currently developing globally, including Indonesia. Therefore, it requires guidelines for tourism management based on sharia principles. The legal provisions regarding tourism management guidelines are based on sharia principles to be regulated in this DSN-MUI fatwa. At the regional level, the urgency of the existence of the Setanggor halal tourism village is also supported by the legal legitimacy in the West Nusa Tenggara provincial government through West Nusa Tenggara Governor Regulation Number 51 the Year 2015 concerning Halal Tourism and West Nusa Tenggara Regional Regulation Number 2 of 2016 concerning Halal Tourism. Considering West Nusa Tenggara (NTB) as one of the halal tourist destinations in Indonesia, the NTB government and all stakeholders provide facilities and services under sharia provisions. The NTB government regulates its management policies to provide security and convenience to tourist services (Adinugraha et al., 2021). 


\section{The implementation of halal value in Setanggor halal tourism villages}

In general, the principle of organizing halal tourism according to the DSNMUI fatwa is to avoid polytheism, immorality, obedience, tabdzir or israf, and create materially and spiritually benefits (Kurniasari, Sawarjuwono, and Ryandono 2019). Based on the principles of halal tourism standardization above, Setanggor village has attempted to implement it in its tourism business because Setanggor has dubbed itself as "Halal Setanggor Tourism Village" and tourism products branded by "Community-Based Halal Tourism." The combination of halal values with this tourist village should always be in line with Islamic law because the teachings of Islam are the best way for people to make perfect trips wherever and whenever they are (Maika and Kautsar 2019).

Internalization of halal values in tourism in Setanggor village, for example, can be seen for foreign visitors accustomed to using loose clothing (not covering their genitals) to be clothed with exceptional Lombok cloth women Setanggor tourism managers. Because based on the DSN-MUI fatwa and West Nusa Tenggara Regional Regulation, tourists must maintain the noble character and adhere to sharia principles by avoiding immorality (Sartika and Adinugraha 2016).

Examples of the implementation of halal values are also packaged in religious tourism in the village of Setanggor, which is in the form of a recitation Quran in berugak (halls in the middle of a stretch of rice field) as well as a place to entertain guests for lunch with the village's unique cuisine. Religious tourism in Setanggor village is different from religious tourism in general, prioritizing pilgrimage tourism as a form of religious tourism.

Religious tourism can be referred to as spiritual tourism (Sholehuddin, Munjin, and Adinugraha 2021), classified into heritage religious sites where tourists who travel can enjoy and learn how the customs, local wisdom, 
Hendri Hermawan Adinugraha et al.

culture, and other knowledge contained in religious tourism objects, so they may get value-added in the form of new knowledge that they do not necessarily get elsewhere (Levi and Kocher 2009).

Setanggor Village also packs its tourist destinations through educational tourism by trying or witnessing the process of making manure into compost and bio-urine. There is also English Fun, where foreign tourists are usually asked to be teachers for elementary, middle, and high school children who take English courses in Setanggor village. Besides, agro-tourism includes cassava planting areas, where tourists can take cassava to be burned and eaten. They can also pick their dragonfruit on an area of 1 hectare.

The phenomenon of educational tourism has recently attracted the interest of economists or investors as a potential type of tourism activity. Educational tourism is helpful in many ways and the best way to help tourists get a new perspective on the world (Junusi, Musahadi, and Yuningrum 2019). Global tourism has aroused the mind to get various cultures and experiences. Educational tourism is an educational and fun learning holiday (Scott, 2017; Jafari and Scott, 2014).

Setanggor village has unique cultural arts, such as gamelan groups, traditional dance and drama, ancient gong instruments, and the tradition of memaos Lontar manuscripts (reading the Sasak ancient manuscripts delivered in groups) involving children, adults, and the elderly. An example of the implementation of local wisdom in Setanggor village is that every citizen must plant at least two sapodilla trees in his yard. It stems from the philosophical value of sapodilla plants as a pioneer plant to grow other plants on infertile soils. Because basically, tourist villages have some unique characteristics to become attractive tourist destinations.

Another unique feature of Setanggor village that can be found in Lombok is that some of Cidomo (typical Lombok horse-drawn carriages) are prepared to explore the visit point. Tourists can also walk along using the Cidomo to the 
resident's villages, rice fields, and irrigation channels. While at night, there is a tour of "River Night." On the evening tour, guests or tourists will get dinner. They sit in a bamboo amben stretched over a river 3 meters wide, entertained by traditional Sasak dance and music, Lombok.

According to Srijaya as the Head of Setanggor Village, the participation of the Setanggor village community can be seen from the direct and indirect involvement of the community in tourism activities and the development of tourist destination areas in each hamlet. Participatory community development in Setanggor village can also be seen in providing overnight services that are integrated with the Setanggor village community. Managers or Pokdarwis have started to provide homestays by implementing a policy that every house has rooms for rent (homestay). Their respective genders separate the tourists who want to spend the night unless those who are married may gather in one room by showing proof of the legality of the marriage. Because in principle, things that violate Islamic law (sharia) in tourism activities are prohibited (ḥarām) from doing so for everyone.

Under DSN-MUI fatwa No: 108/DSN-MUI/X/2016 Concerning Sharia Principles and Tourism Guidelines for West Nusa Tenggara Regional Regulation Number 2 of 2016 concerning Halal Tourism, which essentially means that homestay or hotel cannot provide access to pornography and immoral acts. In principle, according to the DSN-MUI fatwa and West Nusa Tenggara Regional Regulation, all tourist destinations, performances of art, culture, and attractions as long as they do not conflict with sharia principles may be done.

Rural tourism activities in Setanggor were carried out due to the cohesiveness and active participation of the Setanggor village community and the village government. The surrounding community also agrees upon this. Empowering rural communities can mobilize active participation from their communities in development (Iqbal et al. 2019). Therefore, community 
Hendri Hermawan Adinugraha et al.

development in the village is driven by community empowerment so that it can display participatory community development.

\section{Halal tourism village development efforts in Setanggor}

The Setanggor Village area, located in West Praya Subdistrict, set up by the NTB government as a Tourism District, has rural tourism potential. This village has interesting natural characteristics and unique social and cultural life. The village government and its community always develop this potential following the existing socio-cultural characteristics of the community. The development of community-based tourism potential is a strategic effort in building the community (Nova 2021). Therefore, in addition to the active role of the local community and the Setanggor village government, several factors that make Setanggor's halal tourism village develop optimally are as follows:

First, the development of objects and tourist attractions is always carried out by all stakeholders in Setanggor Village, starting from the village government, Pokdarwis, and the community. Setanggor Halal Tourism Village is a manifestation of diversification and innovation of tourist objects used to make tourists or visitors choose Islamic tourism objects and the existing conventional tourist attractions in Lombok.

Second, Development of facilities and infrastructure for the development of the Setanggor Halal Tourism Village include the construction of the "Mertak Mi" art center, providing adequate parking and accommodation areas, centralizing the sale of household handicrafts (souvenirs) and the typical Lombok food home industry labeled halal, Islamic homestay construction, and the construction of Muslim-friendly places of worship. All infrastructures are developed and linked to the economic and social sectors.

Third, the development of other infrastructure that has been built and developed to support the progress of the economic and social sector in Setanggor village is in the form of transportation, communication facilities availability of halal restaurants, camps, visitor service centers, security and 
health facilities, so that overall village facilities and services Halal tourism is available properly.

Fourth, Marketing and promotion of Setanggor halal tourism village have been carried out by stakeholders through offline and online promotional media, such as the website (www.desasetanggor.id), sales mission, Indonesia Tourism Exchange (ITX), magazine or print media, tourism associations, travel agents, television and social media. Setanggor's halal tourist village also has tour package information, general information on tourist villages and village maps, information about potential tourism villages.

Rural tourism development as an alternative tourism product can boost sustainable rural development (Rizki, Agriyanto, and Farida 2019). The development of the Setanggor halal tourism village also follows the principles of rural tourism management: utilizing local community facilities and infrastructure; taking advantage of local communities; taking a small scale to facilitate mutual relations with local communities, 4) Involving local communities; and implementing the development of rural tourism products with specific underlying criteria (Mujanah, Ratnawati, and Andayani 2015).

The development strategy of Setanggor's halal tourism village is also in line with the results of research conducted by Irfan and Suryani (2017), stating that to develop tourism villages requires public participation, cultural preservation, the distinctiveness of regional customs and traditions, the carrying capacity of all elements of society, and the fulfillment or availability of good infrastructure. In essence, rural tourism development is a long-term and potential investment for the government because community resources and natural resources are available (Athief 2019).

The development of Community Based Halal Tourism in Setanggor village leads to a model of tourism development based on the empowerment of local communities (community-based tourism). Conceptually, the basic principle of community-based tourism positions the community as the main 
Hendri Hermawan Adinugraha et al.

actor through community empowerment in various tourism activities so that maximum tourism benefits the community. Community-based tourism is closely related to the participation of local communities with the certainty of benefits. Community participation in tourism consists of two perspectives, namely in local participation in the decision-making process and local participation concerning the benefits received by the community from tourism development (Timothy, 1999; Wijaya and Sudarmawan, 2021; Aprilani, Yuliarmi, and Marhaeni, 2021)

The Setanggor village community has an active role and occupies a vital position. This can be seen from the strong commitment of the Setanggor village community to develop village tourism potential optimally. It also appears that the community occupies a position as the party participating in the subject and object of the tourist village itself. This means that people become direct tourism activities with hereditary experiences in managing natural resources, culture, and economic activities. Moreover, they have a solid commitment to sustainably managing tourism to prosper the lives of local people (Subiyantoro, Zubaidah, and Syauqi 2020).

The empowerment of local communities in the Setanggor halal tourism village follows the objective of establishing Law Number 10 of 2009 to improve people's welfare. This is also following the concept of communitybased tourism, namely tourism activities owned and operated by the community, and managed or coordinated at the community level that contributes to the community's welfare by supporting sustainable livelihoods and protecting valuable socio-cultural traditions, cultural heritage resources, and nature. Furthermore, the community-based tourism standard empowers local communities to determine and secure their socio-economic future through fee-for-service activities (ASEAN Secretariat, 2016).

The development model of "Halal Setanggor Tourism Village," which is based on halal values (halal based) and based on active community participation (community-based), cannot be separated from religious values

Economica: Jurnal Ekonomi Islam - Volume 11, Nomor 1 (2020) https://journal.walisongo.ac.id/index.php/economica 
(the attitude of religiosity of the community), the culture that lives in the community, which then impact on the quality of the environment (Suansri, 2003; Hamzah et al., 2009; Regmi et al., 2015; Purwanto, Rofiq, et al., 2020). This notion is in line with Tajzadeh-Namin (2012), which revealed that the tourism industry is always influenced by religion, especially Islam, because of its specific rules and regulations. Religion has long been an influential factor in tourism, primarily related to halal tourism (Eid and El-Gohary 2015). The influence of religion on tourist movements is a fact that cannot be denied (Mansouri 2014), so religion is not a new focus of tourism studies.

As a consequence of applying this model, the community must commit and try to develop a tourism village to provide attractions to attract tourists, facilities, accessibility, and promotions which can later increase the number of tourists visiting Setanggor village. The attractions that the Setanggor community has made to attract tourists to visit their villages are as follows: Natural Attractions: View Sunset and Sunrise and River Night; Cultural Art Attractions: Gendang Beleq, Dance and Gamelan Class; Legend Attractions: History of Poro Sepuh; Traditional Food Attractions: Cooking Class Cengeh, Ares and Traditional Snacks in Central Lombok.

Tourism management managed by the Setanggor village community seeks to minimize the negative impacts of tourism on the environment and culture. At the same time, the Setanggor village community creates a positive economic impact thanks to village tourism activities. The benefits of developing a halal tourism village Setanggor to the economic and sociocultural aspects felt by the community include the opening of many new job opportunities that will automatically reduce unemployment, increase public income and purchasing power, improve youth education levels in Setanggor, the ability to bear the burden of infrastructure development and local facilities independently, the application and preservation of halal values in travel, protection, and preservation of culture and customs, enhancement of 
Hendri Hermawan Adinugraha et al.

technological skills (Medias, Pratiwi, and Umam 2019), and the use of foreign languages of the local community.

\section{Conclusion}

Among Indonesia's challenges in welcoming the development of halal tourism is the innovation problem in halal tourism destinations. The Halal Setanggor Tourism Village's existence is undoubtedly the answer that Indonesia is genuinely ready to become a halal tourist village destination that attracts domestic and foreign tourists. The development of halal tourism in the countryside is expected to be a model of sustainable tourism development. Setanggor Halal Tourism Village is a new way to develop Lombok tourism that upholds culture and Islamic values. NTB is nicknamed "The Country of a Thousand Mosques," a native Sasak tribe whose majority of the population is Muslim. This form of tourism should provide value-added to the attraction of rural tourism destinations that are more populist to foster economic development in the countryside to accelerate economic growth and the welfare of local communities.

Setanggor halal tourism village developed through active community participation with the village government through the "Community Based Halal Tourism" model in carrying out tourism activities (community-based tourism). The model for developing halal tourism villages in Setanggor combines community-based tourism with halal values (halal-based tourism). Therefore, it becomes a role model for community-based halal tourism. The development of halal tourism in NTB is also inseparable from the support of the NTB Provincial Government and the Indonesian Council of Ulama (MUI) through its regulation and fatwa to develop halal tourism potential. Juridically, this regulation needed to provide legal certainty to the village government and the Setanggor community in managing tourist village areas that implement sharia principles. 
Community-Based Halal Tourism Village ...

\section{References}

Adinugraha, Hendri Hermawan, Ismail Fahmi, Arrauf Nasution, Faisal Faisal, and Maraimbang Daulay. 2021. "Halal Tourism in Indonesia: An Indonesian Council of Ulama National" 8 (3): 665-73. https://doi.org/10.13106/jafeb.2021.vol8.no3.0665.

Adinugraha, Hendri Hermawan, and Mila Sartika. 2019. "Halal Lifestyle Di Indonesia." An-Nisbah: Jurnal Ekonomi Syariah 5 (2). https://doi.org/10.21274/an.2019.5.2.layout.

Ali, Juhary, Mohd Mizan, Mohammad Aslam, Wisma Subang Jaya, and Subang Jaya. 2021. "A Measurement Model of Successful Muslim Entrepreneur" 5 (1): 25-37.

Aprilani, Triana Lidona Aprilani, Yuliarmi Yuliarmi, and AAIN Marhaeni. 2021. "The Role of The Government in Development of Community-Based Tourism on Economic Growth Inclusivity." Journal of The Community Development in Asia 4 (1). https://doi.org/10.32535/jcda.v4i1.1002.

ASEAN Secretariat. 2016. "ASEAN Community Based Tourism Standard." Asean.

Assidiq, Khairul Amri, Hermanto Hermanto, and Baiq Handayani Rinuastuti. 2021. "Peran Pokdarwis Dalam Upaya Mengembangkan Pariwisata Halal Di Desa Setanggor." Jmm Unram - Master Of Management Journal 10 (1A). https://doi.org/10.29303/jmm.v10i1a.630.

Athief, Fauzul Hanif Noor. 2019. "Embedding Crowdfunding Structure in Islamic Venture Capital for SMEs Development." Economica: Jurnal Ekonomi Islam 10 https://doi.org/10.21580/economica.2019.10.1.3186.

Aulia Ramadhani, Sintesa, Masmira Kurniawati, and Jiwangga Hadi Nata. 2020. "Effect of Destination Image and Subjective Norm toward Intention to Visit the World Best Halal Tourism Destination of Lombok Island in Indonesia." $\mathrm{KnE}$ Social

Sciences. https://doi.org/10.18502/kss.v4i9.7318.

Badan Pusat Statistik. 2020. "Statistik Hotel Dan Akomodasi Lainnya Di Indonesia 2019." BPS Statistics Indonesia.

Busaini, Busaini, Baiq Handayani Rinuastuti, Feriyadin Feriyadin, Andrian Wijanarko, Khairul Amri Assidiq, Lalu Ardian Hadinata, and Sintiar 
Hendri Hermawan Adinugraha et al.

Rahmaningsih. 2020. "Peran Pemuda Dalam Membangun Citra Pariwisata Halal Di Desa Setanggor." Jmm Unram - Master Of Management Journal 9 (3). https://doi.org/10.29303/jmm.v9i3.574.

Chin, Wei Lee, Janet Haddock-Fraser, and Mark P. Hampton. 2017. "Destination Competitiveness: Evidence from Bali." Current Issues in Tourism 20 (12). https://doi.org/10.1080/13683500.2015.1111315.

Ciolac, Ramona, Ciprian Rujescu, Simona Constantinescu, Tabita Adamov, Mihaela Cristina Dragoi, and Ramona Lile. 2017. "Management of a Tourist Village Establishment in Mountainous Area through Analysis of Costs and Incomes." Sustainability (Switzerland) 9 (6). https://doi.org/10.3390/su9060875.

DAVIDSON, T. 2005. "What Are Travel and Tourism: Are They Really an Industry?" In Global Tourism. https://doi.org/10.1016/b978-0-75067789-9.50007-8.

Dolezal, Claudia, and Marina Novelli. 2020. "Power in Community-Based Tourism: Empowerment and Partnership in Bali." Journal of Sustainable Tourism. https://doi.org/10.1080/09669582.2020.1838527.

Drăgulănescu, Irina-virginia, and Maricica Druțu Ivan. 2012. "Rural Tourism for Local Economic Development" 2 (1): 196-203.

Eid, Riyad, and Hatem El-Gohary. 2015. "Muslim Tourist Perceived Value in the Hospitality and Tourism Industry." Journal of Travel Research 54 (6): 774-87. https://doi.org/10.1177/0047287514532367.

Feriyadin, Feriyadin, Akhmad Saufi, and Baiq Handayani Rinuastuti. 2021. "Pengembangan Pariwisata Halal Desa Setanggor." Jmm Unram - Master of Management Journal $10 \quad$ (1A). https://doi.org/10.29303/jmm.v10i1a.628.

Gutkevych, Svitlana, and Myroslava Haba. 2020. "Rural Green Tourism: Current Trends and Development Prospects." Informacijos Mokslai 89. https://doi.org/10.15388/im.2020.89.44.

Hamzah, Amran, Zainab Khalifah, Hairul Nizam Ismail, Nur Hasimah Baharudin, Lngeshwary Bhaskaran, and Rosli Nooruddin. 2009. Handbook on Community Based Tourism "How to Develop and Sustain CBT." APEC Tourism Working Group.

Hartiningsih, Monica Fitria, I Made Adhika, and Komang Trisna Pratiwi Arcana. 2017. "The Portrait of Rural Tourism Model in the Baha Tourism 
Village of Badung District." Journal of Business on Hospitality and Tourism 2 (1): 97. https://doi.org/10.22334/jbhost.v2i1.45.

Iqbal, Muhammad, Prameswara Samofa Nadya, Saripudin Saripudin, and Puji Hadiyati. 2019. "Increasing Community Awareness and Intention in Encouraging The Growth of Cash Waqf." Economica: Jurnal Ekonomi Islam 10 (1): 29. https://doi.org/10.21580/economica.2019.10.1.3152.

Irfan, Mohammad, and Any Suryani. 2017. "Local Wisdom Based Tourist Village Organization in Lombok Tourist Area." International Journal of English Literature and Social Sciences 2 (5). https://doi.org/10.24001/ijels.2.5.10.

Jafari, Jafar, and Noel Scott. 2014. "Muslim World and Its Tourisms." Annals of Tourism Research. https://doi.org/10.1016/j.annals.2013.08.011.

Junusi, Rahman El, Musahadi Musahadi, and Heny Yuningrum. 2019. "Balanced Scorecard: Strategy Towards World Class University." Economica: Jurnal Ekonomi Islam 10 (1): 87. https://doi.org/10.21580/economica.2019.10.1.3429.

Kaur, Harmanjot, and Roopjot Kochar. 2017. "Growth of Medical Tourism InIndia: The Current Scenario." International Journal of Scientific Engineering and Applied Science (IJSEAS), no. 3.

Kulak, Nataliia V. 2020. "Modern Development Trends In The Global Tourism Market." Bulletin of the Kyiv National University of Technologies and Design. Series: Economic Sciences $141 \quad$ (6). https://doi.org/10.30857/2413-0117.2019.6.9.

Kurniasari, Widita, Tjiptohadi Sawarjuwono, and Muhamad Nafik Hadi Ryandono. 2019. "Islamic Spiritual Capital Implementation at BMT UGT Sidogiri." Economica: Jurnal Ekonomi Islam 10 (2). https://doi.org/10.21580/economica.2019.10.2.3221.

Lee, Chien Chiang, Godwin Olasehinde-Williams, and Seyi Saint Akadiri. 2021. "Geopolitical Risk and Tourism: Evidence from Dynamic Heterogeneous Panel Models." International Journal of Tourism Research 23 (1). https://doi.org/10.1002/jtr.2389.

Levi, Daniel, and Sara Kocher. 2009. "Understanding Tourism at Heritage Religious Sites." Focus 6 (1). https://doi.org/10.15368/focus.2009v6n1.2. 
Hendri Hermawan Adinugraha et al.

Mai, Thi Khanh Van, and K. I.M. Doo-Chul. 2021. "The Effects of Vietnam's Tourism Development and Payments for Forest Environmental Services Policies on Local Livelihoods in Phong Nha-Ká Bàng National Park Areas." Geographical Review of Japan Series B 93 (1). https://doi.org/10.4157/GEOGREVJAPANB.93.1.

Maika, M. Ruslianor, and Irwan Alnarus Kautsar. 2019. "Hiijrah: Islamic ECommerce Disurpted Strategy." Economica: Jurnal Ekonomi Islam 10 (1). https://doi.org/10.21580/economica.2019.10.1.3217.

Maksimović, Mlađan, Snežana Urošević, and Zvonko Damnjanović. 2015. "Theoretical Concepts of Rural Tourism and Opportunities For Development in the Republic of Serbia." Economics Management Information Technology 3 (3): 162-72.

Mansouri, Shirzad. 2014. "Role of Halal Tourism Ideology in Destination Competitiveness: A Study on Selected Hotels in Bangkok, Thailand." https://doi.org/10.15242/icehm.ed0114528.

Mastercard-CrescentRating. 2018. "Global Muslim Travel Index 2018." Mastercard-Crescentrating.

Medias, Fahmi, Eko Kurniasih Pratiwi, and Khotibul Umam. 2019. "Waqf Development in Indonesia: Challenges Faced by Muhammadiyah Waqf Institutions." Economica: Jurnal Ekonomi Islam 10 (2). https://doi.org/10.21580/economica.2019.10.2.3333.

Miles, Matthew B, and A. Michael Huberman. 1994. "Miles and Huberman 1994.Pdf." Qualitative Data Analysis: An Expanded Sourcebook.

Mohsin, Asad, Noriah Ramli, and Bader Abdulaziz Alkhulayfi. 2016. "Halal Tourism: Emerging Opportunities." Tourism Management Perspectives 19 (2016): 137-43. https://doi.org/10.1016/j.tmp.2015.12.010.

Morrow, Susan L., and Mary Lee Smith. 2000. "Qualitative Research for Counseling Psychology." In Handbook of Counseling Psychology.

Muhamad, Nur Sa adah, Syahnaz Sulaiman, Khairul Akmaliah Adham, and Mohd Fuaad Said. 2019. "Halal Tourism: Literature Synthesis and Direction for Future Research." Pertanika Journal of Social Sciences and Humanities 27 (1): 729-45.

Mujanah, Siti, Tri Ratnawati, and Sri Andayani. 2015. "The Strategy of Tourism Village Development in the Hinterland Mount Bromo, East Java." Journal 
of Economics, Business, and Accountancy | Ventura 18 (1). https://doi.org/10.14414/jebav.18.1.2015.81-90.385.

Nova, Monika. 2021. "Community Tourism - Development of Rural Areas in Developing Countries." SHS Web of Conferences 92. https://doi.org/10.1051/shsconf/20219207043.

Peristiwo, Hadi. 2020. "Indonesian and Malaysian Potential for a Halal Tourism Industry." African Journal of Hospitality, Tourism and Leisure 9 (1).

Purwanto, Hery, Ahmad Rofiq, and Mashudi Mashudi. 2020. "Halal Assurance System (HAS) 23000 Perspective George Robert Terry." International Journal of Islamic Business and Economics (IJIBEC) 4 (2): 63. https://doi.org/10.28918/ijibec.v4i2.2988.

Qiu, Peilei, Zhaoxing Zhou, and Dong Joo Kim. 2021. "A New Path of Sustainable Development in Traditional Agricultural Areas from the Perspective of Open Innovation-a Coupling and Coordination Study on the Agricultural Industry and the Tourism Industry." Journal of Open Innovation: Technology, Market, and Complexity 7 (1). https://doi.org/10.3390/joitmc7010016.

Rahmawati, Rahmawati, Kiki Oktora, Sri Langgeng Ratnasari, Ramadania Ramadania, and Dio Caisar Darma. 2021. "Is It True That Lombok Deserves to Be a Halal Tourist Destination in the World? A Perception of Domestic Tourists." Geojournal of Tourism and Geosites 34 (1). https://doi.org/10.30892/gtg.34113-624.

Rahmiati, Filda, and Anita Rizki Fajarsari. 2020. "The Role Of Religiousity Mediating Islamic Attributes On Tourist Preference At ShariaCompliance Hotel." Jurnal Muara Ilmu Ekonomi Dan Bisnis 4 (1). https://doi.org/10.24912/jmieb.v4i1.7578.

Regmi, Kapil Dev, Pierre G Walter, ZDEL, Timothy R. Hinkin, J. Bruce Tracey, Cathy A. Enz, Riris Harwiyati Riris, et al. 2015. Handbook on Community Based Tourism "How to Develop and Sustain CBT", December 2009. Tourism. Vol. 7.

Rehman, Asad. 2020. "Halal Tourism: Guidelines for Oman." International Journal of Islamic Marketing and Branding 5 (1). https://doi.org/10.1504/ijimb.2020.109060. 
Hendri Hermawan Adinugraha et al.

Rizki, Mita Kurnia, Ratno Agriyanto, and Dessy Noor Farida. 2019. “The Effect of Sustainability Report and Profitability on Company Value: Evidence from Indonesian Sharia Shares." Economica: Jurnal Ekonomi Islam 10 (1): 117. https://doi.org/10.21580/economica.2019.10.1.3747.

Robinson, Peter, Michael Lück, and Stephen Smith. 2020. "An Introduction to Tourism." Tourism, 3-31. https://doi.org/10.1079/9781789241488.0003.

S, Sherri. 2017. "Educational Tourism Is the Best Way to Learn about a Different Culture." Journal of Tourism \& Hospitality 06 (01). https://doi.org/10.4172/2167-0269.1000269.

Sanad, Hassan Saad, Ayman Mounier Kassem, and Noel Scott. 2010. Tourism and Islamic Law. Bridging Tourism Theory and Practice. Vol. 2. Elsevier. https://doi.org/10.1108/S2042-1443(2010)0000002005.

Sartika, Mila, and Hendri Hermawan Adinugraha. 2016. "Implementasi Ijārah Dan Imbt Pada Bank Bri Syariah Cabang Yogyakarta." Economica: Jurnal Ekonomi Islam $\quad 7 \quad 97$. https://doi.org/10.21580/economica.2016.7.1.1034.

Satriana, Eka Dewi, and Hayuun Durrotul Faridah. 2018. "Halal Tourism: Development, Chance and Challenge." Journal of Halal Product and Research 1 (2): 32. https://doi.org/10.20473/jhpr.vol.1-issue.2.32-43.

Shahmirzadi, Esmaeil Khaksar. 2018. "Development of Rural Tourism with a Sustainable Tourism Approach ( Case Study : Shahmirzad City)" 03 (07): 46-51.

Sholehuddin, M. Sugeng, Munjin Munjin, and Hendri Hermawan Adinugraha. 2021. "Islamic Tradition and Religious Culture in Halal Tourism: Empirical Evidence from Indonesia." IBDA': Jurnal Kajian Islam Dan Budaya 19 (1). https://doi.org/10.24090/ibda.v19i1.4470.

Suansri, Potjana. 2003. "Community Based Tourism Handbook." In Community Based Tourism Handbook.

Subiyantoro, Subiyantoro, Siti Zubaidah, and Taufiq Ahmad Syauqi. 2020. "Trash Management Using 'Asset Based Community-Driven Development' to Turn Garbage into Commodity with Creative-Economic Value." International Journal of Health Science and Technology 1 (3). https://doi.org/10.31101/ijhst.v1i3.1279. 
Sukardi, Budi, Fachrurazi Fachrurazi, and Supriyanto Supriyanto. 2019. "Sharia Maqashid's Inclusive Performance and Contribution to The Sharia Non-Bank Financial Industry in Indonesia." Economica: Jurnal Ekonomi Islam 10 https://doi.org/10.21580/economica.2019.10.2.4325.

Tajzadeh-Namin, a. 2012. "Islam and Tourism: A Review on Islamic Republic of Iran." International Journal of Management and Humanity Sciences 1 (1): 17-23.

Taqwiem, Ahsani, Harun Al Rasyid Muhammad, and Ali Maulidi. 2020. "Halal Tourism Development Analysis in Lombok Island." KnE Social Sciences. https://doi.org/10.18502/kss.v4i9.7324.

Tawil, Norngainy Mohd, Shamshubaridah Ramlee, Jauhari Jaafar, and Firdaus Mohd Saat. 2015. "An Overview of Foodpreneur Awareness among Small and Medium-Sized Enterprises (SME) of Halal Certification." Asian Social Science 11 (21): 91-94. https://doi.org/10.5539/ass.v11n21p91.

TAYLOR, G. 2005. "Travel Styles." In Global Tourism. https://doi.org/10.1016/b978-0-7506-7789-9.50023-6.

Thomson Reuters, Dinar Standard. 2018. "State of the Global Islamic Economy Report 2018/19." Dubai International Financial Centre, 112.

Timothy, Dallen J. 1999. "Participatory Planning a View of Tourism in Indonesia." Annals of Tourism Research 26 (2). https://doi.org/10.1016/S0160-7383(98)00104-2.

Utami, Vidya Yanti. 2020. "Dinamika Modal Sosial Dalam Pemberdayaan Masyarakat Pada Desa Wisata Halal Setanggor: Kepercayaan, Jaringan Sosial Dan Norma."Reformasi. https://doi.org/10.33366/rfr.v10i1.1604.

Vanhove, Norbert. 2010. "The Economics of Tourism." Journal of Tourism History 2 (3). https://doi.org/10.1080/1755182x.2010.516898.

Wijaya, Nyoman Surya, and I Wayan Eka Sudarmawan. 2021. "The Potential of Taro Village in Supporting Sustainable Tourism in Gianyar, Bali." Journal of Business on Hospitality and Tourism 6 (2). https://doi.org/10.22334/jbhost.v6i2.227.

Wikantiyoso, Respati, Diyah Sukanti Cahyaningsih, Aditya Galih Sulaksono, Sri Widayati, Dina Poerwoningsih, and Etikawati Triyosoputri. 2021. "Development of Sustainable Community-Based Tourism in Kampong Grangsil, Jambangan Village, Dampit District, Malang Regency." 
Hendri Hermawan Adinugraha et al.

International Review for Spatial Planning and Sustainable Development 9 (1). https://doi.org/10.14246/IRSPSD.9.1_64.

$\mathrm{Xu}$, Keshuai, Jin Zhang, and Fengjun Tian. 2017. "Community Leadership in Rural Tourism Development: A Tale of Two Ancient Chinese Villages." Sustainability (Switzerland) https://doi.org/10.3390/su9122344.

Zabarna, Eleanora, and Tetiana Averikhina. 2020. "The Infrastructural Vector Development of Odessa in the Coordinates of Activation of Tourism Entrepreneurship." Journal of Hygienic Engineering and Design 32.

Zainuddin, Nizamuddin, Adam Mohd Saifudin, Norita Deraman, and Norlila Mahidin. 2019. "Effect of Halal Certification and Labelling Process on Halal Supply Chain Performance." International Journal of Supply Chain Management 8 (4). 